\title{
A Christological approach to poverty in Africa: Following Christ amidst the needy
}

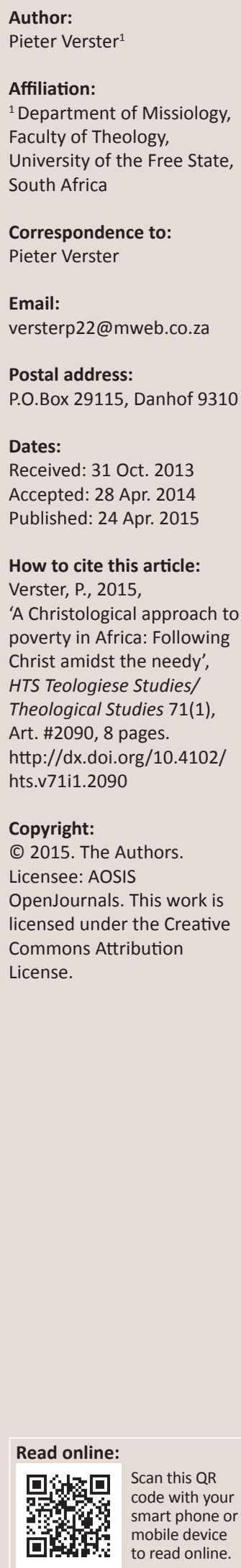

The serious challenges posed by poverty in Africa call for a new approach. A Christological approach to these issues inspires hope. A Christology from above, or 'high' Christology, has much to offer regarding God's looking after humanity. Christ as the one for others humbled himself to give a life of fullness to the poorest and most ill, thereby bringing hope both for this life and for eternity. The approach followed should not lead to the exclusion of people, but rather to an endeavour to meet the challenge of brokenness. In societies where there is no hope left, the Christ of the wounded leads the way to new healing. Christ, verily God and verily human brings us before him in our totality, to be involved in all the needs of the community. The church should be the hands, feet and eyes of Christ for the needy.

\section{Introduction}

The serious challenges posed by poverty in Africa call for a new approach. It is very clear that no solution has as yet been found for these challenges. Positive developments are often hampered by serious negative factors that prevent these developments from materialising in practice. Can a Christological approach inspire hope? Christology always played a pivotal role in the discussion on poverty alleviation and eradication in the Christian theology. The view was and is often taken that a Christology from below, emphasising Christ's humanity, is the best way of approaching poverty. As a human condition, poverty should be challenged radically. No stone should be left unturned to deal with the crisis. However, a theology from above, emphasising Christ's Divinity, gives essential help in dealing with poverty, exactly because it puts emphasis on the glory of God. Christ's Divinity is so glorious but also so full of implications for the life of humans that it cannot be disregarded. Is it not essential to also deal with poverty from the perspective of Christology from above to deal with far reaching implications of God's involvement in the human predicament? From a Reformed perspective the essence of God's involvement in the human reality is always seen from Christ's Divine Sonship.

The methodology used entails the evaluation of the challenges facing Africa concerning poverty. A background study of these challenges is described and explained. The views of theologians reflecting their different opinions on Christology from above and below are then evaluated. The views from African theologians in this regard are also important. Exegetical and theological implications of Christology regarding the addressing of poverty are then put forward. Thereafter possible solutions with a view to meeting the challenges are discussed in the light of these implications.

Can a Christology from above offer a solution with a view to dealing with and resolving the absolute challenges of poverty? On the basis of this central question, the following related questions can be asked: how can the church, in following the wounded Christ of God, become the healer of the needy?; and how can new relations be formed from the perspective of the Christ as God of the Cross and Resurrection?

\section{The situation in Africa}

The well-known Africa Progress Report monitors the situation in Africa in an excellent and highly relevant way. Africa Progress Report 2010 refers to many issues in respect of which Africa still needs to be developed in order to arrive at a better situation. On the economic level, debt, unemployment, poor infrastructure, and corruption still pose serious challenges. Africa has to deal with the inhibitory effect of these factors. The Africa Progress Report (2010:15) points out that the crisis intensified in that year. The collapse in trade and financial flows resulted in that, for the first time since 1994, the real GDP growth rate in sub-Saharan Africa was not sufficient to match the population growth (2.5\%), resulting in a fall in per capita income. The Africa Progress Report (2011:11) refers to the then present situation: 'Africa's current economic growth is not all positive. It is generally not accompanied by much needed structural transformation and 
diversification, and often does not translate into equitable human development and public services.'

Reference is made to the fact that sub-Saharan Africa is home to nearly one third of the world's poor, and that their absolute numbers have increased from 268 million to 306 million over the last decade. It is estimated that the number of poor Africans may even be as high as 458 million (Africa Progress Report [2011:27]). The Africa Progress Report (2012:8) and The Africa Progress Report (2013:11) observe that much progress in Africa has been made but that the situation is still grave and, although economic development is present, poverty remains on extremely high levels. The Africa Progress Report (2013:8) states: 'It is a matter of grave concern that Africa is not on course for achieving the 2015 Millennium Development Goals (MDGs)', but also states that with good governance and economics the future may be much more positive.

The HIV and AIDS epidemic on the continent shows no signs of abating ${ }^{1}$ and the number of deaths resulting from this is still very high. The issue of how these challenges should be approached is still of cardinal importance.

The causes of poverty in Africa, as highlighted by Chibuye, include the following:

- Inequitable distribution of resources.

- Misplaced priorities: this refers to the fact that the basic problem in Africa is not a lack of resources, but rather the misguided identification of priorities.

- The debt trap: it is pointed out that foreign debt has been suffocating many African countries for a long time.

- The trade trap: it is an incontrovertible fact that trade can contribute to poverty eradication, if rightfully practised.

- The conflict maze: this refers to the fact that impoverishment is often the result of a region's proneness to conflict (Chibuye 2009:253ff.).

For these reasons, Chibuye (2009:253ff.) emphasises that impoverishment is beyond politics and economics - it is, in fact, a moral issue (see also Majawa 1998:258). Ayedze (2009:194) writes: 'The truth is that colonialism, postcolonialism, and the international financial institutions, as well as African leaders and intellectuals, share various degrees of responsibility for this gloomy situation of Africa.'

Van der Walt (2003:11ff.) refers to post-colonial economic development in Africa. He points out that certain issues have been addressed, but that very often, no positive indications have emerged.

Mombo (2009:224) explains that Africa is marginalised tremendously by the burgeoning technological advancements

1.Pinn (2009:231) explains how colonialism denuded Kenya of its resources, with devastating consequences. Other aspects, such as trade deficits, international debt and governmental mismanagement of funds also had a profound influence on the povery situation in Africa. Issues such as the har hatural environment, the runa the present greed of the rich world, should also be addressed. This means that in Africa, a whole range of circumstances operating together, including environmental, economic, social and political factors, lead to poverty O'Connor (1991:3ff.). and profound geopolitical realignments. Africa lacks technological power and political muscle to be a major roleplayer in the global forums: 'It appears then that Africa has no choice other than to use all available opportunities to transform herself while resisting the pressure and influence of the very powerful neighbours with whom she shares the planet.'

Christianity also did not always inspire entrepreneurship. It was as if the soul was all important and not the present reality. ${ }^{2}$ Although much was carried out to help poor people, Africa did not benefit as it should have because of the lack of comprehensive education in financial issues and entrepreneurship. The challenges are enormous and although real progress has been made, Africa still faces serious issues with regard to poverty. These challenges have to be met.

\section{Reaching the poor}

O'Connor (1991:1) writes: 'To think of Africa is to think of poverty.' Certainly, this premise is changing - and must be changed. Poor people need to be approached in a holistic manner, in terms of which all aspects of their lives are addressed. Poverty is an extremely difficult human condition to define. Usually, definitions explicitly refer to the lack of adequate food, housing, infrastructure and health care. The \$1-a-day-perperson median is sometimes used to define the minimum level of poverty. There are other authors, however, who emphasise that poverty should be regarded as a human condition encompassing far more than just the economic aspects. Factors such as social, cultural, religious and judicial relations should also be taken into account. 'Vulnerability' is regarded by some as a more appropriate word for describing the poverty of people in Africa. Cilliers and Wepener define poverty as 'a state of affairs where the absence of material resources, the denied space for trust and identity forming, as well as the loss of civil skills impact negatively on one another, in a seemingly unstoppable and negatively escalating spiral' (Cilliers \& Wepener 2007:44, in Wepener et al. 2010:64). Poverty may also include aspects such as being deprived of opportunities to learn in order to obtain better employment in order to escape poverty and to enjoy the respect of fellow citizens (Das 2009:vii).

Conditions that are not conducive to human dignity can also be emphasised as aspects linked to poverty. These aspects include varying degrees of disempowerment at various levels, and the psychological stress occasioned by these conditions (Chibuye 2009:244).

The evaluation of poverty should, however, make provision for the possibility of progressive and ultimately

2.BJ van der Walt (2003:54-55) draws attention to the fact that a wrong kind of Gospel is often taught in Africa - a Gospel characterised by dualism between faith and the needs of the world. Christ brings us before him in our totality to be involved and the needs of the world. Christ brings us before him in our totality to be involved in all the needs of the community. Van der Walt (2003:55) points out that in Africa the Gospel was very often distorted by an exclusive emphasis on the spiritual conversion to Christ, without a corresponding focus on how this conversion should influence one's decisions and actions in the context of everyday life. This exclusive emphasis very often caused people to separate their daily lives from their church life. Church was for Sundays, whilst 'normal life' was conducted from Monday to Saturday. This led to dualism, as a result of which the Christian Gospel did not have an influence on the everyday lives of people. 
transformative social change, according to Jones (2005:999). This means that the evaluation of poverty must not stop at identifying causes to which the problem can be attributed, but that a new and radical approach is necessary. The Christian approach to poverty is thus very important; and the acknowledgement of the human dignity of people in terms of such an approach is paramount (Myers 1999:58).

\section{A Christological approach}

In a Christological approach, the essence of Christ, truly God and truly human, the one for others, should be established. Christological perspectives are important in order to ascertain the implications of God's relationship to the poor. The Divinity of Christ should be proclaimed because this is the way in which he changes the human condition. Therefore, a section on such perspectives is necessary.

\section{Perspectives on Christology The Reformed perspective}

The perspective of this article is from a Reformed view where the emphasis falls on Christ as truly God and truly human and the encompassing role he plays in regenerating the world. In this tradition the emphasis is on God, his glory and his involvement in this world. Calvin (1960:482ff.), however, clearly distinguished between the Divinity of Christ and his earthly existence. ${ }^{3} \mathrm{He}$ did, however, adhere to a high Christology. From this perspective, Calvin (1960:526ff., 684ff.) emphasised the radical governance of God in the lives of all. This includes life lived in poverty. The poor are not accorded preferential treatment, but should be approached in terms of the full implications of God's presence as Creator and Saviour. However, in Christ, God also calls for responsibility and justice. ${ }^{4}$ This life on earth has limited importance, because the future life with God is secured. Calvin writes (1960:499): 'Thus it is that we may patiently pass through this life with its misery, hunger, cold, contempt, reproaches, and other troubles - content with one thing: that our King will never leave us destitute, but will provide for our needs until our warfare ended, we are called to triumph.' Misery because of sin, however, also has implications for poverty, although poverty cannot only be only attributed to sin. For Calvin (1960:498) this earthly life passes by and the real happiness belongs to the heavenly life. However, this does not mean that this life is unimportant, but rather that everything is

3.The well-known extra-calvinisticum emphasises exactly the high regard of Calvin for the eternal Divine Sonship of Christ (Van der Kooi 2008:297).

4.De Gruchy (2009:106) explains how Calvin, like a prophet of old, set himself against the ostentatious luxury of the aristocratic and wealthy classes. See also De Gruchy 2009:206. McGrath (1990:323) discusses the Weberian theses on capitalism and Calvinism but then says: 'A degree of critical detachment must accompany Christian affirmation of the world as God's creation and gift. Christians are to live in the world while avoiding falling into that world, becoming immersed within and swallowed by it.' It is clear that for Calvin God calls us to responsibility and not exuberance. Britz (2008a:488) also refers to the fact that Calvin rejected any inhuman treatment of others especially of the poor. Britz (2008b:15) explains how Calvin links the providence of God, the knowledge of God and poverty: 'Calvin thus links poverty, or to be struck by poverty to the knowledge of God as Creator and Saviour, in or to be struck by povert, to the knowledge of God as Creator and Saviour, in particular to knowledge living God, the God of Abraham, Jacob and Isaac, the Father of Jesus Christ the Lord. God may not be distanced from this world and history. In his inscrutable Deitas Dei he is unconditional immediate. A very important contribution is made by Edmondson (2004:32) who states that for Calvin Christ's divinity is involved in the very act of mediation, which means that he is able to fully mediate in the total redemption of humans before God. subordinate to heavenly life. Did Calvin (1960:699) consider the full consequences of his Christology in his views on poverty? For him, to live with God is the essence of life. This means that God in Christ expects the human being, whether rich or poor, to be responsible to God.

\section{Karl Barth}

Although Barth adhered to the Reformed tradition, and although, in his Christology, he emphasised God's looking after human beings, some present-day researchers of Barthian theology are of the opinion that Barth's view of God is largely inferred on the basis of his radical politics. His views on materiality are therefore regarded as being based on a radical socialistic way of thinking. However, this interpretation can be challenged. Barth (1980:5ff.) emphasised that the incarnation of Christ in this world as the Son of God demonstrated that God had said 'yes' to the world. God drew near to the world (see Waldrop 1984:167). God is the one who, in his Son Jesus Christ, reached out to the world in the midst of its problems and challenges.

Barth's understanding of the incarnation should be examined more closely. ${ }^{5}$ The issue is that Christ yielded himself for the sake of mankind. 'God with us' also means that 'we with God' is enclosed in faith. Faith, hope and love can only be through God. 'Our faith, love and hope - live only by that we cannot create, posit, awaken or deserve' (Barth 1980:15). God in his majesty in Jesus Christ, his Son, opens up the possibility of total wretched beings to become new in faith. Entering into the lives of humans God totally changes the possibilities of humans. God makes it new. In the most challenging situation of extreme poverty it is God as God who reaches out to humans.

Barth's radical politics may have led to a totalitarian view of politics. His view on the incarnation should, however, be interpreted in terms of the implication of God's radical upliftment of the poor in giving them new hope and initiative. ${ }^{6}$ The misery of humans is the misery of the person in sin. However, in Jesus Christ the human becomes a new person. Poverty is not regarded as sin but it is an aspect of misery. Barth (1978:493) comments: 'The liberation of man from his misery has taken place and is a fact only in the royal freedom in which the man Jesus has accomplished it by giving up Himself, His life as very God and very man, to death for us in obedience to God and as our Lord and Head and Representative.' This is only possible through an acceptance of humanity. The implication is, however, that it must still be recognised that God remains the 'ganz Andere'; and only in accepting this can human beings experience life.

5.Hunsinger (2000:134) explains the full implications of Barth's Christology: "The person of Jesus Christ, who is at once truly God and yet also truly human, does not exist apart from his work, nor his work apart from his person. Rather, his unique person is in his work even as his saving work is in his person.'

6.Krötke (2000:174) writes: 'Anthropology, as Barth understood it, can and must be lived out as a practical anthropology in the Christian community and in the lives of individual Christians in the midst of society and in opposition to all the lives of individual Christians in the midst of society and in opposition to all the
inhumanity that reigns there; it must be lived out in active service of a better human righteousness.' 


\section{Liberation theology}

Liberation theology places a predominant emphasis on materiality. Jesus' historical existence on earth is proclaimed, and is put forward as a radical explanation and motivation for the outreach to the poor and despised. In this regard, Sobrino's Christology is of importance. Sobrino (1978:370374) works with the notion of the 'radical' Christ of the revolution. He refers to the fact that Jesus had zealots in his group of disciples. Radical influences pertaining to poverty, as well as a total change in the situation of poverty, remain essential elements of liberation theology. Sobrino (1978:201) writes: 'In historical terms God is to be found in the crosses of the oppressed rather than in beauty, power or wisdom.' This Christology emphasises the freedom and initiative of the poor, who become material beings of hope. However, it discards the eschatological future with the eternal Christ. Sobrino (1994:30) argues that in the church of the poor, Christ becomes present, and that this church is his body in history. This has the implication that it is not his body automatically, but only in so far as it offers Christ as the liberating hope and action, and that in suffering, it can make him present as risen and as crucified.

The question to be asked is whether this approach does not emphasise humanity as the answer to its own problems without taking into account that the serious situation calls for radical Divine intervention. Sobrino (1994:248), however, links the essential meaning of the cross to God being also small and lesser; God's transcendence must be radically redefined: 'God does not show himself in a positive challenge, but in silence.' Sobrino (1994:248) continues: 'The cross reveals, not power, but impotence. God does not triumph on the cross over the power of evil, but succumbs to it.' This should be challenged from the perspective of Christ's Divinity.

\section{African theologians}

There are different ways in which African theologians explain Christology. Mugambi (1992:143) states that contemporary Africa calls for new implications with regard to the Christological emphasis on the future. The ultimate question of destiny remains all-important. Stinton (2004:19) refers to African Christological texts from theologians such as Bujo, Ela, Mugambi, Wasike, Oduyoye and Pobee. Manus (1993) also emphasises Christology from an African perspective. The notion of Christ as the African king is suggested by him. The concept of Jesus as life giver is proposed by Bujo and Pobee (Stinton 2004:54ff., 57ff.) The traditional African concept of life is regarded as highly relevant for understanding that Jesus is the one that gives this fullness of life. Oduyoye is yearning for the wholeness of life and healing. Ela also find the aspect of healing important for Christology as Jesus is the healer (Stinton 2004:62). Although the notion of Jesus as traditional healer is also present it is not mentioned by the theologians listed by Stinton (2004:80). Jesus as mediator is clearly linked to the ancestors and theologians such as Bujo and Oduyoye find in Jesus the companion on life's journey from the perspective of the ancestors (Stinton 2004:109). Other concepts used are Jesus as loved one, for example brother or even mother (Stinton 2004:143ff) and Jesus as leader (Stinton 2004:177). Manus is of the opinion that Christ as the African king represents Christology the best in the African context. He writes:

From the insights of the African traditional kingship cultures and the NT history, I offer a horizon in which Jesus of Nazareth relates to Africans as the Christ and Lord of history. This understanding of the biblical Christ in the light of a specific African cultural paradigm has far-reaching implications in the church and society. It points up the historical and cosmic relevance of the kingship of Christ for the life and praxis of Christians in today's Africa. (Manus 1993:239)

The importance of Christology in dealing with the challenges of Africa must not be underestimated. New Testament Christologies also used concepts of the known environment such as logos. The regeneration of the concepts should however enhance the full realisation of the glory of Christ. Caution must be called for not to mistake Christ for an African ancestor or king without taking into consideration that he is, as Divine and human, also vastly different from any human form.

Mugambi (1992:145) spells out the implications of African Christologies. The followers of Jesus proclaimed the new era in human history (Mugambi 1992:145). This means that it should be understood that in the new Africa, the concept of salvation needs to be reinterpreted. Mugambi (1992:141) views the Christian approach to history as one approach amongst many, which should not be presented as the only one. He writes (1992:89): 'Here and now, the kingdom of God is within the reach of all those who individually and collectively live according to the ideal demands of the kingdom of God.' These views should be challenges for the essence of Christ as the only one that is truly God and truly human.

\section{Implications}

These theologians emphasise different aspects of Christology in dealing with poverty alleviation. They are good examples of the approach of Christology from above (Calvin and Barth) but also from below (Sobrino). Lastly, the implications of Christology for the African experience are also relevant (Manus, Mugambi and others). It is important to realise that these theologians show how essential a Christological approach to the alleviation of poverty is. The questions asked by these approaches should be evaluated by turning to an exegetical and hermeneutical study of biblical texts. A biblical Christology will be developed to come to helpful conclusions on the aspect of the implications of Christology for the crises of poverty in Africa.

\section{The incarnation: A biblical perspective}

There is a general view that Christology from below is the best approach in terms of its implications for the deliverance of people in need. Christology from above, however, offers significant potential for a change in communities brought 
about by the living God. Christ's Divinity establishes the possibility of a new perspective on poverty, because God himself is involved. It is God who becomes the new life for human beings. In Christ God is present. In Christ he is the one for others.

Christ as the one for others humbled himself to give a life of fullness to the poorest and most ill. Life in its fullness means a personal relationship with God, with hope in this world, but also - especially - with hope for the future world, entailing a life lived with God. Life in its fullness bears the implication of a healed existence, in which the person experiences the nearness of God in the midst of the needs of life.

In Philippians 2, Paul emphasises that Christ was the image of God and took on the life of a human being in order to draw near to people. This passage of scripture can be regarded as an early hymn (Homer 1980:122). Christ humbled himself to become human for the sake of people. In his pre-incarnate status, he existed in the form of God (Homer 1980:123). ${ }^{7} \mathrm{He}$ humbled himself to the point of death on the cross. In this regard Hawthorne (1983) writes:

But contrary to what one might expect, the true nature of God is not to grasp or get or selfishly to hold on to things for personal advantage, but to give them up for the enrichment of all. This is demonstrated by Christ, who, because he shared the nature of God, did not hold firm to the high position that was his by right, but rather stepped down from it. That is to say, he deliberately placed himself in the humblest of positions: he who was in the form of God became a man, a fully human being, a slave even, so that he might serve others. (p. 95)

The use of the word morphe (Phlp 2:6) to explain Christ's relation to God emphasises that the outward manifestation corresponds to the essence, whereas the term schema would only imply that the outward appearance is temporary (Homer 1980:123).

Three aspects are usually referred to concerning harpagmon, (Phlp 2:6) pertaining to the notion that Christ did not need to grasp equality:

- The pre-incarnate Christ already possessed equality with God the Father and resolved not to cling to it.

- Christ had no need to grasp at equality with God, because he already possessed it.

- Christ did not need to reach for his crowning prematurely, as Adam did, but was willing to wait until his suffering had been accomplished (Homer 1980:123).

However, Scott and Wicks ([1955] 1990:48) emphasise that Christ did not wish to steal what belongs to God.

Homer also points out that the mode of existence of Christ as co-equal with God was hardly something that pertained only to the future. When Christ became man, he did not lay

\footnotetext{
7 Kärkkäinen (2013:180) explains that Dunn's views of Christology in the making of the divinity of Christ as a development in Christian theology should be rejected, because the pre-existence of Christ as professed in Philippians 2 can hardly be misunderstood.
}

aside his Divine attributes, but only the insignia of the Divine image (Homer 1980:123-124).

In Philippians, however, Paul already laid the foundation for the high Christology. Craddock (1985:40) writes: 'Because in Jesus of Nazareth they experienced God, the Christians used pre-existence as one way of saying that in the very human, crucified Nazarene they had encountered reality beyond all contingencies of time, place and history.'

A high Christology, or Christology from above, emphasises the radical aspects of the incarnation. Coming from God, Christ is God with us. Kysar (1978:354) emphasises the fullness of the humanity of Christ in the incarnation as glory: 'The incarnation is real, but so is the glory perceptible in the incarnate one. The implications of the suggestion that the humanity of Christ is not a humiliation but a continued exaltation do not challenge the authenticity of the humanization of the logos.' Cullman (1963:276) explained this aspect more fully at an earlier stage by pointing out that, being the Son of God, Jesus appears not only as a miracleworker and saviour like many others, but as radically and uniquely distinct from other men, as he knows that he has been sent to others to fulfil his task in complete unity with the Father

Kärkkäinen (2013:154) discusses the full implications of the Divinity of Jesus Christ. He emphasises the incarnation as something new entering into the Divine life: 'This of course is not to speak of the change in God in a way that would compromise God's deity, but rather to speak of God's own choice from eternity to be united with humanity, created in his own image.'

However, this also links up with the far-reaching implications of the incarnation for the person in need. In Christ, God is involved in the human condition. He, as God, in the incarnation in Christ radically changes the views of humans. He is God for the humans.

Acknowledging the validity of a high Christology, Imasogie (1983:24), however, also explains that it should be presented to Africans in terms of a perspective that fits in with their world view. He writes: 'This is what we mean by insisting that Christ, the Eternal Word, must once again, as it were, become incarnate in the culture and thought patterns of the people if he is not to be seen as a foreign god who is unacquainted with the local metaphysical problems of the African.'

\section{The life of Christ}

It is therefore also important to consider the life of Christ. It is important at the outset to emphasise that only the Divine Christ can show true compassion towards those in need because he in his Divinity reaches out to humans in need. To accomplish this he yielded himself to become human. In Matthew 4:23-25, by healing people, Christ showed that people in the most desperate situations were important to 
him. People who were blind, those who were lame, lepers, all of those on the fringes of the community, were in the sight of Christ. His attentive gaze fell upon those with the greatest needs; and he empowered them with the fullness of life through his salvation. Jesus' ministry included preaching, teaching and healing, which encapsulated his whole ministry (Hagner 1993:81).

Freyne (2009:297) is of the view that Jesus began his reinterpretation of the idea of messiahship in Galilee, where, according to the Synoptic Gospels, he formulated his understanding of the kingdom of God and his role in its arrival. Malbon (1999:129) refers to the implications of the narrative, and points out the need to appreciate a more complicated narrative arrangement in terms of which the protagonist, Jesus, presents a unique point of view about himself in relation to God (which is, precisely, a central concept of 'Christology'). It is 'a point of view enacted in his words and deeds.'

From an African perspective theologians refer to the benevolent role of the king in an African context. Manus (1993:96) explains the African king has an encompassing role to play. They provide protection, are the rulers of law, and are the persons to provide spiritual and physical benevolence. Accepting that Christ indeed provides benevolence it may be possible to relate to him from this perspective. Caution should however be taken that the African king is not the true Divine revelation of God as he is in Christ.

\section{Christ's power in brokenness}

From the perspective of Christ's power in brokenness, it is clear that he also placed special emphasis on people living on the fringes of society, namely women, lepers, tax collectors, as well as others who were very poor and vulnerable. The glory of Christ is especially relevant in that he in his Divinity, exactly as Son of God, identified with humans in the greatest need. Schreiner (2008:764) points out how the theme of concern for those in need pervades Luke. In following Christ, the church had to look after those in poverty.

In Luke 10:21-24, the language used by Luke shows Jesus as the mysterious Son of Man, announcing his suffering, rejection and death, but also his resurrection on the third day. Jesus is portrayed as the Christ, but is also depicted in his suffering (Nolland 1993a:467). Luke 14:7-14 refers to the blessing that arises from the inability of those benefited by one's hospitality to provide any kind of return (Nolland 1993a:751). Jesus' love for those on the fringes of the community is demonstrated in his call for compassion.

Here the difference from African kings and the ancestors should be regarded as important. The kings and ancestors are not wounded and despised for the benefit of the community. Christ the wounded one reveals God in his compassion for others. The implication is that these Christological aspects have essential consequences for the practical life and work of the church. This must not be underestimated.

\section{The church following in the footsteps of Jesus \\ Following the wounded Christ to see the wounded people}

The problem is that often the church does not perceive its role in terms of the regenerating and salvific manner in which Christ as God became human and saved the world. Salvation must be regarded as total and radical, encompassing the future and the present. Christ looked at people in their humanity. ${ }^{8}$ Acknowledging the fullness of God in Christ, we should also acknowledge the radical salvation in him. The wounded Christ is the Christ of the people alongside the road; he is the Christ of those who have no abode. In Luke 23:26-43, Jesus, as the wounded one, faces his death (Nolland 1993b:1139). Maimela (1994:28) states that God alone is selfsufficient, and that he calls us to life in interdependence with others, in order to be truly human.

It is necessary to explain that the incarnation of God in Christ is the aspect in terms of which we must consider God's looking after human beings; and this seeking after humanity is also the radical acceptance of the redeeming of the poor and marginalised by God. All this concerns the redemption of human beings by God in all aspects of humanity. But it is - precisely - Christ, as the Son of God, who fulfils the full salvation of body and spirit (see also Pinn 2009:242). The full implications of this seeking after human beings by God, in the person of Christ, are also applicable to the most needy. This is the implications of the Divine Son becoming human.

Orobator explains how the incarnation is essential for understanding this:

[T]he incarnation is here proposed as an essential theological principle necessary for understanding the function, meaning and theology of the church in situations of HIV/AIDS, refugees and poverty. God does not stand apart from the complexity and vicissitudes characteristic of these conditions (Orobator 2005:242).

\section{Christology and the poor}

In the light of the foregoing, Christology is very important. A Christology from above that has far-reaching implications for people's ordinary lives needs to be argued and implemented in the church's presence and work - a Christology that acknowledges Christ as the one from God but also Jesus as the wounded Christ for those who desire to become part of his community. But he is also - precisely - God, dwelling amongst human beings in order to lead them to God.

\section{Christ of the people}

Christ is the one amongst others, in the sense that he is the one who was wounded for all the others, enabling them to reach out towards him and become part of his community.

8.Majawa (1998:261) writes that the church should lead the people to :......... know their rights as well as obligations, protect the environment, work hard to eradicate their rights as well as obligations, protect the environment, work hard to eradicate
ignorance, poverty and disease, etc. Alleviation of poverty and suffering in Africa has to be at the centre of the church pastoral planning.' 
They are invited to become part of the community of faith and to share in the goodness of the resurrected Christ - the one who heals, and who is there in his humanity to help them and to fill them with his presence.

Craddock (1968:166) states that the poverty of Christ consists in the identification of him with the human situation, an identification without reservation. Therefore, the church, by also becoming 'wounded' in this community, can share in the 'brokenness' of Christ, so that its members can become healers in the community. Being wounded and broken themselves, the members of the church can experience the healing of the Christ whom they are following; and as followers of Christ, they can also experience the healing of the resurrected Christ. Therefore, they should also be those who heal others in the community, and in doing so, they should bring about new hope in a seemingly hopeless situation. The eradication of poverty must remain the most essential goal.

We cannot emphasise the redemption of human beings without referring to Christ as God who became human. In him, the poor receive a new status as human beings before God. The full redemption, however, is both spiritual and material. Harrison (1994:153) explains that Christ saves through the incarnation, by uniting the whole of the human composite and all aspects of human experience with himself as God. Through his Divine presence, he purifies what is sinful and sanctifies what is good. Johnson (1996:20) refers to the parable of the pearl of great price and explains that poor people, although they might not receive justice, may sometimes experience the fullness of God's intervention at the very time when they are left with no recourse except to trust in God. Njoronge (2009) explains:

Hence, the task of political, cultural, spiritual, material, and psychological transformation and renewal demands that religious scholars create biblical, theological, and ethical resources that will help people to cultivate and nurture their faith in God, in themselves, and with one another, so as to acquire meaningful living and fully participate in society. (p. 180)

Bosch (1991:387) points out the important distinction in terms of which a church should always be the church with others (the poor). The true emphasis of the church is to be always next to the one in need.

It is interesting that there are churches in Africa reaching out to the poor in a uniquely African way. These churches often have limited means, but are present in a profound way amongst the poor. As pointed out by Oduro et al. (2008):

The AIC pastors do not preach about difficult, abstract concepts to the poor or the uneducated. They relate the Gospel to the needs, and they show God's power at work in ways that all people can understand. The AIC church buildings are usually simple places, not that different from the homes where poor people live. The poor feel like they are in their own church, and not in someone else's fancy church. (p. 209)

The African Independent Churches (AICs) also listen to the problems of people (Oduro et al. 2008: 84): 'Many people come to the AICs after they have been to medical doctors, nurses, diviners or herbalists for help. What they find is people willing to take time to listen to their problems, take their worldview and beliefs seriously, care for a person as an individual.'

Ezigbo (2008:69) points out that, essentially, '... a Christian Christology that hopes to be relevant and meaningful to the peoples of Africa should allow for a dialectical or a mutual interaction between the biblical representations of Jesus Christ and the histories and experiences of Africans.' Bujo (1992:91) calls for the whole of African life to be built on Jesus Christ for a truly dynamic Christianity, conceived in specifically African categories. An African Christocentric ethic should be established.

However, does a Christology from above also open the way for authentic involvement in African issues? In Africa, the full acknowledgement of God as involved in the totality of life is all-important.

\section{The future perspective}

The future perspective is therefore also important. In Christology, it is necessary to keep sight of the fact that Christ, who is the wounded Christ, is also the healed Christ, and therefore points towards a new future; an eschatological future in which healing and peace are possible. The community of Christ, following Christ, must therefore also direct people to the new life and the new future; and for the poor in Africa, this has significant implications. Their vulnerability may still be with them; but they look towards the future, and this new future, offering the prospect of a life lived in Christ, makes it possible for them to look forward to the new situation. In this sense, it is also a positive aspect of living with Christ - and abiding with him, with a view towards the future. Especially in Africa this future aspect should be emphasised. The Son of God leads to the future. He makes a new future possible.

\section{Conclusion}

There are many challenges in Africa and the possibilities of alleviating poverty on the continent still leave much to be desired. This article engages the crises in Africa as well as the serious problems in dealing with these crises. Secondly the implications of Christology were discussed and the profound glory of Christ's Divinity and the radical change which that can bring about were explained. Exactly God in Christ's involvement in the human condition can bring about change. There should be a shift from our own efforts to the realisation in the church of the full implications of God's involvement in humans' predicament. Only when the church accepts the radical involvement from God can a new situation be accomplished.

\section{Acknowledgements}

This article is based upon research supported by the National Research Foundation (NRF) of South Africa. Any opinions, 
findings, conclusions or recommendations expressed in this material are those of the author: the NRF shall not be subject to any liability in respect thereof. The research was also supported by the University of the Free State (UFS) cluster, 'New frontiers in poverty reduction and sustainable development'.

\section{Competing interests}

The author declares that he has no financial or personal relationship(s) that may have inappropriately influenced him in writing this article.

\section{References}

Africa Progress Report, 2010, From agenda to action: Turning resources into results for people, UN, Geneva, viewed June 2010, from http://www.africaprogresspanel.org.

Africa Progress Report, 2011, The transformative power of partnerships, UN, Geneva, viewed May 2011, from http://www.africaprogresspanel.org.

Africa Progress Report, 2012, Jobs, justice and equity: Seizing opportunities in times of global change, UN, Geneva, viewed July 2013, from http://www. africaprogresspanel.org.

Africa Progress Report, 2013, Equity in extractives: Stewarding Africa's natura resources for all, UN, Geneva, viewed July 2013 from http://www. africaprogresspanel.org.

Ayedze, T., 2009, Poverty among African people and the ambiguous role of Christian thought, in P.J. Paris (ed.), Religion and poverty: Pan African perspectives, pp. 193-212, Duke University Press, Durham.

Barth, K., 1978, Church dogmatics: The doctrine of reconciliation, transl. G.W. Bromiley, vol. iv, part 2, T\&T Clark, Edinburgh.

Barth, K., 1980, Church dogmatics: The doctrine of reconciliation, transl. G.W. Bromiley, vol. iv, part 1, T\&T Clark, Edinburgh.

Bosch, D.J., 1991, Transforming mission: Paradigm shifts in theology of mission, Orbis, Maryknoll, NY.

Britz, D., 2008a, De politiek en het social leven, in H.J. Selderhuis (ed.), Calvijn Handboek, pp. 485-496, Kok, Kampen.

Britz, R.M., 2008b, Paupertas (Poverty) in John Calvin's Institutes, in V.E. D'Assonville \& R.M. Britz, R.M., (eds.) Prompte et sincere: Johan Calvin and the exposition of the Word of God, Acta Theologica Supplementum 10, 1-24.

Bujo, B., 1992, African theology in its social context, Orbis, Maryknoll, NY.

Calvin, J., 1559/1960, Institutes of the Christian religion, Vol. 1, (Edited by John T. McNeill; translated by F.L. Battles), Westminster, Philadelphia.

Chibuye, M., 2009, Poverty and social justice in the AMECEA Countries, African Ecclesial Review 51(3) S 2009, 242-260.

Cilliers, J.H., \& Wepener, C.J., 2007, Ritual and the generation of social capital in contexts of poverty: A South African exploration. International Journal of Practical Theology 11(1), 39-55.

Craddock, F.B., 1985, Philippians. Interpretation: A Bible commentary for teaching and preaching, John Knox Press, Atlanta.

Craddock, F.B., 1968, The poverty of Christ. An investigation of 2 Cor 8:9. Interpretation 22(2), 158-170.

Cullmann, O., 1963, The Christology of the New Testament, (Translated by S.C. Guthrie \& C.A.M. Hall), SCM, London.

Das, K., 2009, Poverty: Issues and challenges, Sonali Publications, New Delhi.

De Gruchy, J.W., 2009, John Calvin: Christian humanist and evangelical reformer, Lux Verbi.BM., Wellington, SA.

Edmondson, S., 2004, Calvin's Christology, Cambridge University Press, Cambridge.

Ezigbo, V.I., 2008, Rethinking the sources of African contextual Christology, Journal of Theology for Southern Africa 132 (November), 53-70.

Freyne, S., 2009, The Galilean Jesus and a Contemporary Christology, Theological Studies 70 (2009), 281-297.

Hagner, D.A., 1993, Matthew 1-13, Word Biblical Commentary. Vol. 33A. Word Books, Dallas, Texas.

Harrison, V.E.F. 1994. Poverty, social involvement and the life of Christ according to St Gregory the Theologian. Greek Orthodox Theological Review 39 (1/2), 151-164.

Hawthorne, G.F. 1983. Philippians. Word Biblical Commentary. Vol. 43. Word Books, Waco, Texas.

Homer, A.K., Jr., 1980, Philippians, in F.E. Gaebelein, The expositor's Bible commentary, Vol. 2., pp. 93-160, Zondervan, Grand Rapids, Mi.
Hunsinger, G., 2000, Karl Barth's Christology: its basic Chalcedonian character, in I. Webster, (ed.), The Cambridge companion to Karl Barth. pp. 127-142, Cambridge I. Webster, (ed.), The Cambridge
University Press, Cambridge.

Imasogie, O., 1983, Guidelines for Christian theology in Africa. African Christian Press, Achimota.

Jones, B.G., 2005, Africa and the poverty of international relations, Third World Quarterly 26(6), 987-1003.

Johnson, S.E., 1996, The message of Jesus to the poor and the powerful, Anglican Theological Review, 11 March 1996 - Supplement series, 16-28.

Kärkkäinen, V-M., 2013, Christ and reconciliation: A constructive Christian theology for the pluralistic world, Vol. 1, Eerdmans, Grand Rapids, Mi.

Krötke, W., 2000, The humanity of the human person in Karl Barth's anthropology, in I. Webster (ed.), The Cambridge companion to Karl Barth, pp. 159-176. Cambridge Webster (ed.), The Cambridge
University Press, Cambridge.

Kysar, R., 1978, Christology and controversy: The contributions of the prologue of the gospel of John to New Testament Christology and their historical setting, Currents in Theology and Mission 5(6), 348-364.

Maimela, S.S., 1994, What is the human being? Prestige Lectures 1, South Africa in the Balance, University of Pretoria, Pretoria.

Majawa, C., 1998, The churches' prophetic role in the struggle against poverty in Africa, African Ecclesial Review 40(5/6), 258-270.

Malbon, E.S., 1999, "Reflected Christology": An Aspect of Narrative "Christology" in the Gospel of Mark, Perspectives in Religious Studies 26(2), 127-145.

Manus, U.C., 1993, Christ, the African King: New Testament Christology, Peter Lang, Frankfurt am Main.

McGrath, A.E., 1990, A life of John Calvin: A study in the shaping of Western culture, Basil Blackwell, Oxford.

Mombo, E.M., 2009, Religion and materiality: The case of poverty alleviation, in P.J. Paris (ed.), Religion and poverty: Pan African perspectives, pp. 213-227, Duke University Press, Durham.

Mugambi, J.N.K., 1992, African Christian theology: An introduction, East African Educational Publishers, Nairobi.

Myers, B.L., 1999, Walking with the poor, Orbis Books, New York.

Njoronge, N.J., 2009, The struggle for full humanity in poverty stricken Kenya, in P.J. Paris (ed.), Religion and poverty: Pan African perspectives, pp. 166-192. Duke University Press, Durham.

Nolland, J., 1993a, Luke 9:21-18:34, Word Biblical Commentary. Vol. 35b, Word Books, Dallas, Texas.

Nolland, J., 1993b, Luke 18:34-24:53, Word Biblical Commentary. Vol. 35c, Word Books. Dallas, Texas.

O'Connor, A., 1991, Poverty in Africa: A geographical approach, Belhaven Press, London.

Oduro, T., Pretorius, H., Nussbaum, S. \& Born, B., 2008, Mission in an African way: A practical introduction to African Instituted Churches and their sense of mission, CLF, [s.I.].

Orobator, A.E., 2005, From crisis to kairos: the mission of the church in the time of HIV/ AIDS, refugees and poverty, Paulines, Nairobi.

Pinn, A.B., 2009, Warm bodies, cold currency: A study of religion's response to poverty, in P.J. Paris (ed.), Religion and poverty: Pan African perspectives, pp. 228-248, Duke University Press, Durham.

Schreiner, T.R., 2008, New Testament theology: Magnifying God in Christ, Baker Academic, Grand Rapids, Mi.

Scott, E.F. \& Wicks, R.R., [1955] 1990, The Epistle to the Philippians: The interpreter's Bible: A commentary in twelve volumes, vol. 11, Abingdon, Nashville.

Selderhuis, H.J., (ed.), 2008, Calvijn handboek, Kok, Kampen.

Sobrino, J., 1978, Christology at the crossroads: A Latin American approach, (Translated by J. Drury), SCM, London.

Sobrino, J., 1994, Jesus the liberator: A historical-theological reading of Jesus of Nazareth. (Translated by P. Burns and F. McDonagh). Orbis, Maryknoll, N.Y.

Stinton, D.B., 2004. Jesus of Africa: Voices of contemporary African Christology. Orbis, Maryknoll, N.Y.

Tanner, K., 2010, Christ the key, (Current issues in theology), Cambridge University Press, Cambridge.

Van der Kooi, C., 2008, Christologie, in Selderhuis, H.J. (ed.), Calvijn handboek, pp. 290-299, Kok, Kampen.

Van der Walt, B.J., 2003, Understanding and rebuilding Africa: From desperation today to expectation for tomorrow, ICCA, Potchefstroom.

Waldrop, C.T., 1984, Karl Barth's Christology: Its basic Alexandrian character, Mouton, Berlin.

Webster, J., (ed.) 2000, The Cambridge companion to Karl Barth, Cambridge University Press, Cambridge.

Wepener, C., Swart, I., Ter Haar, G. \& Barnard, M., 2010, The role of religious ritual in social capital formation for poverty alleviation and social development: Theoretical and methodological points of departure of a South African exploration, Religion \& Theology, 17, 61-82. 